\title{
TEORI PECKING ORDER DAN TRADE-OFF DALAM ANALISIS STRUKTUR MODAL DI BURSA EFEK INDONESIA
}

\author{
D. Agus Harjito \\ Prodi Manajemen Universitas Islam Indonesia Yogyakarta \\ e-mail: agus_h@uii.ac.id
}

\begin{abstract}
This study aims to test the pecking order theory and trade-off theory of capital structure in the analysis of the Indonesia Stock Exchange. Pecking order theory is represented by the variable profitability and growth, while the variables volatility of earnings, tangibility of assets and the size represents a trade-off theory. The company's goal is prosperity of shareholder value. To achieve these objectives the company needs funds from internal sources and external sources. Internal sources in the form of retained earnings, while the external sources of debt and shareholders' approval in theecking order theory. This study uses the data of financial ratios of the firms during the period 2000-2010. To analyze the data, this study uses a multiple regression with the dependent variable is the debt ratio, while profitability, growth, volatility of earnings, tangibility of assets and size as independent variables. The results show that asset structure and company size has a positive and significant impact on capital structure, while profitability has a negative effect on debt ratios. But company's growth rate has not relationship with the debt ratio or capital structure. Simultaneously, the all independent variables affect capital structure significantly.
\end{abstract}

Keywords: pecking order, trade-off, capital structure, debt rasio

\begin{abstract}
Abstrak
Penelitian ini bertujuan untuk menguji teori pecking order dan teori trade-off dalam analisis struktur modal di Bursa Efek Indonesia. Teori pecking order diwakili oleh variabel profitability dan growth, sementara variabel-variabel volatility of earnings, tangibility of assets dan size mewakili teori trade-off. Tujuan perusahaan adalah memakmurkan nilai pemegang saham. Untuk mencapai tujuan tersebut perusahaan membutuhkan dana yang diperoleh dari sumber internal dan sumber eksternal. Sumber internal berupa laba ditahan, sedangkan sumber eksternal berupa hutang dan saham sebagaimana dijelaskan dalam teori pecking order. Data yang digunakan dalam penelitian ini berupa rasio-rasio keuangan dari perusahaan sampel selama periode tahun 2000-2010. Metode analisis yang digunakan adalah regresi berganda dengan variabel terikat adalah debt ratio; sedangkan profitability, growth, volatility of earnings, tangibility of assets dan size bertindak sebagai variabel bebas. Hasil analisis menunjukkan bahwa struktur asset dan ukuran perusahaan memiliki pengaruh positif dan signifikan terhadap rasio hutang perusahaan. Sementara variabel proftabilitas memiliki efek negatif terhadap rasio hutang. Sedangkan tingkat pertumbuhan perusahaan tidak ditemukan memiliki hubungan yang signifikan dengan rasio hutang. Secara simultan, variabel-variabel bebas dapat mempengaruhi rasio hutang secara signifikan.
\end{abstract}

Kata Kunci: pecking order, trade-off, struktur modal, rasio keuangan

\section{PENDAHULUAN}

Teori pecking order (pecking order theory) dalam analisis struktur modal dikembangkan oleh Myers dan Majluf (1984). Berdasarkan teori ini, sumber utama modal perusahaan yang pertama kali harus berasal dari hasil usaha perusahaan yang berupa keuntungan bersih setelah pajak yang tidak dibagikan kepada para pemilik perusahaan atau pemegang saham (laba ditahan). Laba ditahan ini akan diinvestasikan kembali dalam usaha atau proyek perusahaan yang menguntungkan. Jika laba ditahan tidak 
cukup untuk membiayai proyek investasi yang menguntungkan tersebut, maka perusahaan dapat meningkatkan modalnya dengan mencari dana dari hutang dan kemudian dari modal sendiri atau ekuitas (Myers dan Majluf, 1984). Urutan struktur modal ini menjelaskan mengapa teori pecking order muncul sebagai salah satu teori struktur modal yang menjelaskan bagaimana perusahaan membiayai kegiatannya.

Teori struktur modal menjelaskan perimbangan antara hutang jangka panjang dan modal sendiri (ekuitas). Teori struktur modal tidak relevan dalam kaitannya dengan nilai perusahaan telah diusulkan oleh Modigliani dan Miller (1958). Jika hutang dapat meningkatkan nilai perusahaan (Modigliani dan Miller, 1963) karena adanya penghematan dalam model pajak, maka perusahaan harus mempertimbangkan trade off antara biaya yang ditimbulkan karena kesulitan keuangan (financial distress), biaya agensi (Jensen dan Meckling, 1976) dan manfaat pajak, sehingga tercapai rasio hutang yang optimal. Namun, teori pecking order menyatakan bahwa adanya target rasio hutang yang diinginkan perusahaan untuk mencapai nilai perusahaan tertentu (Frank dan Goyal, 2005).

Model pecking order berargumen bahwa teori ini muncul karena adanya asimetri informasi antara perusahaan dan para pemodalnya. Oleh karena itu munculah hirarki pembiayaan perusahaan yang dimulai dengan laba ditahan yang memiliki biaya asimetri informasi terendah, diikuti oleh hutang, dan akhirnya ekuitas atau modal sendiri dari sumber eksternal yang memiliki biaya asimetri informasi tertinggi. Asimetri informasi merupakan kekuatan yang didorong oleh teori pecking order yang banyak terjadi di negara-negara berkembang termasuk Indonesia. Oleh karena itu, Indonesia dengan pasar modal yang sudah relatif maju akan menjadi tempat yang baik untuk menguji secara empiris teori pecking order kaitannya dengan penilaian kinerja perusahaan.

Salah satu faktor penting dalam membuat keputusan pembiayaan (financing) adalah hubungan antara struktur modal riil perusahaan dan struktur modal optimal (Brigham dan Ehrhardt, 2005). Telah dijelaskan sebelumnya bahwa struktur modal merupakan gabungan pembiayaan jangka panjang yang terdiri dari hutang jangka panjang dan modal sendiri yang terdiri dari saham istimewa dan saham biasa. Struktur modal mempunyai pengaruh penting terhadap keuntungan dan stabilitas perusahaan. Proporsi hutang yang lebih besar dapat meningkatkan pertumbuhan keuntungan yang tinggi, tetapi disisi lain hutang yang besar akan memperbesar kemungkinan kebangkrutan bagi perusahaan, terutama apabila hutang tersebut menyebabkan pertumbuhan perusahaan tersebut kecil atau bahkan negatif.

Pada model struktur modal, suatu tingkat hutang optimal ditetapkan dengan mempertimbangan biaya dan manfaat (cost and benefit) yang berkaitan dengan leverage perusahaan. Dalam analisis struktur kepemilikan hutang, secara teori banyak model yang digunakan untuk membuat ramalan atas pemilihan sumber hutang di dalam suatu struktur modal perusahaan. Model pemilihan sumber hutang dengan asumsi bahwa hutang bank dan hutang bukan bank adalah sama. Namun demikian, terdapat hasil empirikal yang memisahkan hutang bank dan mengkombinasikannya dengan hutang bukan bank. Johnson (2003) menemukan bukti adanya perbedaan antara hutang bank dan hutang swasta bukan bank. Dengan demikian ia membedakan antara hutang bank, hutang publik dan hutang bukan bank. Yang menjadi masalah selanjutnya adalah faktor-faktor apakah yang menentukan pemilihan sumber penggunaan hutang atau struktur kepemilikan hutang.

Struktur modal (capital stucture) adalah perbandingan atau imbangan pendanaan jangka panjang perusahaan yang ditunjukkan oleh perbandingan hutang jangka panjang terhadap modal sendiri. Pemenuhan kebutuhan dana perusahaan dari sumber modal sendiri berasal dari modal saham, laba ditahan, dan cadangan. Jika dalam pendanaan perusahaan yang berasal dari modal sendiri masih mengalami kekurangan (defisit) maka perlu dipertimbangkan pendanaan perusahaan yang berasal dari luar, yaitu dari hutang (debt financing). Namun dalam pemenuhan kebutuhan dana, perusahaan harus mencari alternatif-alternatif pendanaan yang efisien. Pendanaan yang efisien akan terjadi bila perusahaan mempunyai struktur modal yang optimal. Struktur modal yang optimal dapat diartikan sebagai struktur modal yang dapat meminimalkan biaya penggunaan modal keseluruhan atau biaya modal rata-rata, sehingga memaksimalkan nilai perusahaan. 
Berkaitan dengan struktur modal tersebut di atas, maka sistem keuangan perusahaan merupakan salah satu pertimbangan yang perlu dianalisis. Setiap perusahaan memiliki kebijakan sendiri untuk memutuskan kebijakan apa yang digunakan untuk membiayai bisnisnya dengan tujuan utama untuk memaksimalkan nilai perusahaan sekaligus mengurangi risiko keuangan perusahaan. Dalam literatur keuangan perusahaan, teori struktur modal merupakan salah satu masalah yang paling membingungkan. Seperti telah kita ketahui bahwa strategi perusahaan untuk membiayai aset mereka adalah melalui kombinasi dari ekuitas, hutang, dan laba ditahan. Dengan menganalisis faktor-faktor yang mempengaruhi struktur modal, perusahaan dapat menentukan jenis kebijakan keuangan yang dikeluarkan.

Bentuk dari teori struktur modal seperti dikemukakan oleh Modigliani dan Miller (1958) mulai menjadi dasar pemikiran modern pada struktur modal. Karena faktor-faktor penting yang dapat menentukan keputusan struktur modal umumnya dipandang sebagai hasil murni teoritis. Mereka mencetuskan bahwa struktur modal tidak relevan kecuali dalam sebuah pasar sempurna, maka ketidaksempurnaan yang ada di dunia nyata harus menjadi penyebab relevansinya. Teoriteori struktur modal seperti teori pecking order dan teori trade-off mencoba untuk menunjukkan beberapa ketidaksempurnaan ini dengan asumsi yang dibuat dalam model Modigliani dan Miller (1958).

Menurut teori yang ada, struktur modal secara signifikan mempengaruhi nilai perusahaan. Mislnya $\mathrm{t}$ eori trade off, tujuannya adalah untuk menjelaskan fakta bahwa perusahaan biasanya dibiayai sebagian dengan hutang dan sebagian dengan ekuitas. Hal ini menyatakan bahwa ada keuntungan untuk membiayai dengan hutang, yaitu adanya penghematan pajak yang harus dibandingkan dengan biaya kemungkinan kesulitan keuangan termasuk biaya kepailitan hutang. Argumen ini sesuai dengan pendapat Hovakimian, et al. (2001). Mereka menemukan bahwa lebih menguntungkan apabila perusahaan menggunakan hutang daripada ekuitas. Di sisi lain, pendapat ini mendukung penerapan teori pecking order. Pendapat tersebut didukung adanya keuntungan yang diperoleh perusahaan jika diterapkan teori trade-off dan juga teori pecking order yang dikaji oleh Frank dan Goyal (2005).

Sesuai dengan kajian sebelumnya, maka tujuan penelitian ini adalah untuk menganalisis faktor-faktor penentu keputusan kebijakan hutang perusahaan yang terdaftar di BEI (Bursa Efek Indonesia). Penelitian ini merupakan kelanjutan penelitian sebelumnya yang telah dilakukan oleh Taufik dan Harjito (2010). Mereka menemukan hubungan yang signifikan antara teori fiskal, trade off dan pecking order dalam menentukan rasio hutang. Hasil penelitian ini diharapkan dapat menambah bukti empiris mengenai pemahaman teori keuangan khususnya teori trade off dan pecking order dalam analisis struktur modal.

Pada dasarnya, penelitian ini ingin mengetahui faktor-faktor penentu kebijakan hutang bagi perusahaan di Indonesia berdasarkan teori trade-off dan teori pecking order dalam teori struktur modal. Kemudian peneliti akan melakukan investigasi apakah struktur modal dapat mempengaruhi kinerja keuangan perusahaan-perusahaan di Indonesia.

\section{KAJIAN PUSTAKA}

Penelitian mengenai struktur modal perusahaan cukup banyak didiskusikan oleh para akademisi setelah Miller dan Modligiani (1958) yang mmengemukakan tentang teori irrelevansi dalam struktur modal perusahaan. Mereka menyatakan bahwa struktur modal tidak mempunyai pengaruh terhadap nilai perusahaan, akibatnya pembahasan teori keuangan hanya bertumpu pada tiga persoalan yaitu teori irrelavan, faktor penentu struktur modal dan struktur modal optimal. Perkembangan teori keuangan mengenai struktur modal terutama berkaitan dengan teori irrelevan Miller dan Modligiani mendapat tanggapan beragam sehingga melahirkan teori baru yang dikenal dengan teori trade-off, teori pecking order dan teori agency.

Teori trade-off menyatakan bahwa hubungan antara struktur modal dengan nilai perusahaan terdapat suatu tingkat leverage yang optimal. Menurut teori ini agar tercapai struktur modal yang optimal perusahaan perlu menyeimbangkan agency cost of financial distress dan the tax advantage of debt financing. Menurut teori ini struktur modal yang optimal dicapai, apabila nilai sekarang dari tax shield 
hutang adalah sama dengan nilai sekarang dari biaya kesulitan keuangan hutang. Secara umum teori ini menegaskan bahwa apabila perusahaan ingin meningkatkan nilai perusahaan melalui indikator earning per share (EPS), maka pembiayaan investasi tambahan hurus dibiayai oleh hutang. Hal ini terjadi karena pembiayaan dengan hutang, perusahaan dapat memperoleh penghematan pajak sekaligus mempertahankan jumlah saham beredar. Keadaan ini mendorong pendapatan per lembar saham (EPS) akan lebih tinggi. Sebaliknya apabila perusahaan mengalami kegagalan dalam mengelola investasi yang berakibat pada ketidakmampuan membayar bunga dan pokok pinjaman, maka posisi perusahaan berada diambang kebangkrutan. Apabila semua biaya akibat kesulitan keuangan tersebut sama dengan jumlah tambahan pendapatan dari penghematan pajak (taxe shield of debt), maka struktur modal perusahaan dianggap sudah optimal.

Teori pecking order menyatakan bahwa perusahaan melakukan keputusan pendanaan secara hierarki dari pendanaan internal ke eksternal. Urutan pendanaan mulai dari dana yang bersumber dari laba ditahan, kemudian hutang dan akhirnya sampai pada penerbitan ekuitas baru, artinya dimulai dari sumber dana dengan biaya termurah (Myers dan Majluf, 1984). Teori pecking order ini menganut keputusan pendanaan dengan urutan preferensi logis investor terhadap prospek perusahaan dan konsisten pada tujuan, agar manajer mampu memaksimumkan kemakmuran pemegang saham. Teori pecking order mengasumsikan bahwa perusahaan cenderung memilih pembiayaan internal untuk mendanai proyek-proyeknya. Perusahaan juga menyesuaikan target devidend pay-out ratio dengan kesempatan melakukan investasi. Di samping itu perusahaan menerapkan kebijakan deviden yang kaku, fluktuasi profitabilitas dan kesempatan berinvestasi yang unpredictable. Keadaan ini menyebabkan dana yang dihasilkan dari kegiatan internal seringkali tidak digunakan sesuai dengan kebijakan pengeluaran modal (capital expenditure). Apabila dana internal lebih besar maka perusahaan akan menggunakannya untuk melunasi hutang atau berinvestasi pada surat berharga. Sebaliknya apabila perusahaan mengalami defisit, maka perusahaan akan menurunkan saldo kas atau menjual surat berharga tersebut. Asumsi lainnya bahwa ketika perusahaan memerlukan sumber dana tambahan, mereka cenderung memilih hutang lebih dulu kemudian sekuritas (Myers dan Majluf, 1984).

Teori agensi merupakan teori yang berhubungan dengan masalah agensi. Menurut teori ini potensi konflik antara agen-agen yang terlibat dalam perusahaan baik itu manajer, bondholder maupun shareholder menentukan struktur modal optimal yang akan meminimalkan biaya agensi (agency costs). Menurut Myers dan Majluf (1984), perusahaan yang memiliki peluang pertumbuhan yang tinggi di masa depan harus menggunakan pembiayaan ekuitas yang lebih besar, karena penggunaan leverage yang tinggi berarti membiarkan peluang investasi yang menguntungkan.

Penjelasan di atas menunjukkan bahwa teori trade-off dan teori pecking order menyatakan adanya tingkat hutang yang optimal yang menyamakan biaya marjinal atas hutang terhadap manfaat marjinal dari hutang tersebut. Jika ada penyimpangan dari tingkat hutang yang optimal, maka perusahaan membuat upaya untuk menyesuaikan kembali ke tingkat hutang yang optimal mereka. Sementara dalam teori lain, seperti teori keagenan, menyatakan bahwa proporsi peningkatan hutang di satu sisi dan peningkatkan proporsi ekuitas di sisi lain dapat mencapai struktur modal yang optimal sehingga akan meminimalkan total biaya agensi. Oleh karena itu, teori trade-off dan teori pecking order menekankan manfaat dan biaya hutang, sedangkan teori keagenan menekankan biaya keagenan ekuitas dan hutang dari suatu struktur modal yang bersangkutan.

Teori trade-off dan teori keagenan menyatakan bahwa terdapat rasio hutang yang optimal atau struktur modal yang optimal di dalam keuangan perusahaan. Namun sebaliknya, perusahaan membuat keputusan struktur modal berdasarkan sumber modal yang paling mahal biaya modalnya. Itu adalah sumber modal yang kurang sensitif terhadap masalah asimetri informasi yang mengikuti urutan srukturnya, yaitu mulai dari laba ditahan; diikuti oleh hutang dan terakhir ekuitas.

Teori pecking order dalam rangka menjabarkan hubungan antara struktur modal, dividen perusahaan dan kebijakan investasi. Teori ini menunjukkan bahwa perusahaan lebih suka menggunakan laba ditahan untuk membayar dividen dan membiayai investasi baru. 
Hal ini berarti peringkat laba ditahan di bagian atas urutan kekuasaan, diikuti oleh hutang dan ekuitas terakhir eksternal. Teori pecking order memprediksi adanya hubungan negatif antara keuntungan dan rasio hutang. Selanjutnya, teori pecking order juga menunjukkan bahwa struktur modal perusahaan yang diamati memiliki hubungan yang positif dengan ukuran, pertumbuhan dan kekayaan atau aset perusahaan. Bagi perusahaan yang menguntungkan dengan prospek pertumbuhan yang lambat akan memiliki rasio hutang yang relatif rendah terhadap rata-rata industri di mana perusahaan tersebut beroperasi. Di sisi lain, perusahaan yang tidak menguntungkan dalam industri yang sama akan memiliki rasio hutang yang relatif tinggi dibandingkan dengan rata-rata industri mereka. Dengan demikian, tingkat keuntungan akan menentukan pilihan perusahaan jika akan memerlukan modal eksternal. Alasan utama mengapa teori pecking order ditafsirkan memiliki hubungan negatif antara rasio hutang dan keuntungan adalah bahwa pembayaran dividen dianggap erat kaitannya dengan keuntungan dan besarnya hutang. Oleh karena itu, perusahaan akan mempunyai pilihan untuk membayar hutang yang akan menyebabkan penurunan rasio hutang dengan meningkatnya keuntungan. Artinya bahwa, apabila keuntungan meningkat maka kemampuan perusahaan untuk membiayai investasinya dari hasil keuntungan akan meningkat. Di sisi lain, meningkatnya keuntungan akan meningkatkan pertumbuhan perusahaan.

Mengikuti studi sebelumnya yang dirumuskan oleh Mira (2001) dan berdasarkan apa yang telah dipaparkan pada kajian pustaka sebelumnya, hipotesis yang diajukan adalah sebagai berikut:

H1: Pertumbuhan memiliki hubungan positif dengan leverage perusahaan.

H2: Struktur aset memiliki hubungan positif dengan leverage perusahaan.

H3: Ukuran perusahaan memiliki hubungan positif dengan leverage perusahaan

H4: Ada hubungan negatif antara profitabilitas dan leverage perusahaan.

\section{METODE PENELITIAN}

\section{Sampel Penelitian}

Sampel data penelitian diperoleh dengan metode purposive sampling di mana data yang diperlukan berdasarkan kriteria tertentu, yaitu: 1) Perusahaan-perusahaan yang terdaftar dalam Bursa Efek Indonesia sejak tahun 2000-2010. 2) Perusahaan-perusahaan yang memiliki sumber pendanaan dari ekuitas, hutang dan juga memperoleh laba bersih selama periode penelitian.

\section{Variabel Penelitian}

Untuk menganalisis faktor-faktor yang menentukan struktur modal perusahaan berdasarkan teori trade-off dan pecking order diperlukan variabel penelitian yang berupa rasio-rasio keuangan perusahaan yang bersangkutan. Secara terinci, variabel penelitiannya adalah sebagai berikut: a) Rasio Hutang (Debt Ratio). Ukuran ini menunjukkan tingkat solvabilitas perusahaan dan risiko potensial yang dihadapi perusahaan atas beban hutangnya. Hal ini akan memberitahukan kepada kita berapa besar jumlah hutang yang digunakan untuk membiayai aktivanya. Rasio total hutang terhadap total aktiva diformulasikan sebagai berikut:

$$
\text { Rasio total hutang }(\text { DEBT })=\frac{\text { Total Hutang }}{\text { TotalAktiva }}
$$

b) Pertumbuhan Perusahaan (Growth). Perusahaan-perusahaan dengan peluang tumbuh yang lebih tinggi akan menghadapi masalah dalam investasi yang lebih berat. Agar dapat mengatasi masalah tersebut, perusahaanperusahaan berupaya untuk menggunakan hutang jangka pendek.

$$
\begin{gathered}
\text { Peluang Pertumbuhan }(\text { GROWTH })= \\
\frac{\text { Perubahan Aktiva tangibel }}{\text { Perubahan Aktiva Total }}
\end{gathered}
$$

c) Struktur Aktiva (Asset Structure). Teori trade-off mengemukakan bahwa perusahaan besar pada umumnya mempunyai kemungkinan bangkrut yang relatif kecil dibandingkan perusahaan kecil sehingga lebih mudah untuk melakukan pinjaman ke bank. Biasanya, karena adanya biaya hutang, kreditur cenderung memerlukan jaminan untuk meminjamkan uang mereka (dapat diwujudkan dalam aktiva jaminan). Aktiva jaminan tersebut nilainya ditetapkan seperti nilai jika terjadi kasus likuidasi perusahaan tersebut. Formula struktur aktiva tersebut adalah: 
Struktur Aktiva (Asset) $=\frac{\text { AktivaTangibel }}{\text { Aktiva Total }}$

d) Ukuran perusahaan (Size). Ukuran perusahaan berpengaruh negatif terhadap rasio leverage, artinya makin besar suatu perusahaan maka akan makin mudah mendapatkan dana melalui penjualan saham baru, sehingga hutang akan makin berkurang. Seperti ditunjukkan dalam kajian Mira (2001) bahwa perusahaan-perusahaan besar cenderung memiliki kapasitas yang besar untuk bertahan dan diversifikasi, sehingga antara ukuran perusahaan dan kemungkinan untuk bangkrut memiliki hubungan kebalikannya. Ukuran perusahaan (S) dihitung dengan mencari Logaritma natural dari total aktiva, $\mathrm{S}=\mathrm{Ln}$ total aktiva. c). Tingkat Keuntungan (Profitability). Profitabilitas berpengaruh negatif terhadap rasio leverage. Hal ini sesuai dengan Teori pecking order yang menyatakan bahwa apabila profitabilitas perusahaan makin tinggi maka akan meningkatkan sumber dana internal Sehingga penggunaan hutang menjadi makin rendah. Myers dan Majluf (1984) menganggap bahwa berdasarkan pada pembiayaan pecking order, perusahaanperusahaan mendahulukan untuk menggunakan sumber modal internal, kemudian baru sumber modal eksternal berupa hutang dan ekuitaas. Hal ini menunjukkan bahwa perusahaan yang lebih menguntungkan akan cenderung menggunakan pembiayaan dari laba ditahan sebelum menggunakan hutang atau modal sendiri (ekuitas). Formula untuk mengukur profitabilitas adalah sebagai berikut:

Profitabilitas (PROFIT): ROA $=\frac{E A T}{\text { Aktiva Total }}$

\section{Metode Analisis}

Penelitian ini dianalisis menggunakan regresi berganda untuk menemukan faktor-faktor yang menentukan struktur modal yang ditunjukkan oleh rasio hutang terhadap total aset (debt ratio). Desain model analisis datanya adalah sebagai berikut:
DEBT $=\beta_{0}+\beta_{1}$ GROWTH $+\beta_{1}$ ASSET $+\beta_{1}$ SIZE $+\beta_{1}$ PROFIT $+e$

di mana:

DEBT $=$ Debt Ratio

GROWTH $=$ Growth Opportunities

ASSET $=$ Asset Structure

SIZE $=$ Firnize

PROFIT $=$ Profitability

$\beta_{1 . .4}=$ regression coefficient

$\beta_{0}=$ Constant .

$\mathrm{e} \quad=$ Random error

\section{HASIL PENELITIAN}

Bagian ini mendiskusikan hasil analisis data yang digunakan. Analisis digunakan bantuan program EVIEWS versi 5 untuk melihat adanya common effect dan fixed effect dari data panel yang ada. Tabel 1 menunjukkan hasil analisis dengan model common effect sebagai berikut:

Table 1: Hasil Regresi Panel dengan model Common Effect

\begin{tabular}{|c|c|c|c|c|}
\hline Variable & Coefficient & Std. Error & t-Statistic & Prob. \\
\hline $\mathrm{C}$ & -0.123748 & 0.076287 & -1.652176 & 0.0871 \\
\hline GROWTH & -0.217283 & 0.032938 & -2.167234 & 0.0426 \\
\hline ASSET & -0.023847 & 0.052162 & -0.923641 & 0.3452 \\
\hline SIZE & 0.110938 & 0.023172 & 9.239476 & 0.0021 \\
\hline PROFIT & -0.537454 & 0.076395 & -6.362724 & 0.0000 \\
\hline \multicolumn{5}{|l|}{ Weighted Statistics } \\
\hline R-squared & \multicolumn{3}{|c|}{0.832837 Mean dependent var. } & 0.730231 \\
\hline Adjusted R-squared & 0.812472 & \multicolumn{2}{|c|}{ S.D. dependent var. } & 0.41373 \\
\hline S.E. of regression & 0.254127 & \multicolumn{2}{|c|}{ Sum squared resid. } & 3.227732 \\
\hline F-statistic & $85.2 \theta \quad 22$ & \multicolumn{2}{|c|}{ Durbin-Watson stat } & 0.571201 \\
\hline Prob. (F-statistic) & 0.000011 & & & \\
\hline \multicolumn{5}{|l|}{ Unweighted Statistics } \\
\hline R-squared & 0.33882 & \multirow{2}{*}{\multicolumn{2}{|c|}{$\begin{array}{l}\text { Mean dependent var. } \\
\text { S.D. dependent var. }\end{array}$}} & 0.503438 \\
\hline Adjusted R-squared & 0.302815 & & & 0.235127 \\
\hline S.E. of regression & 0.171542 & \multirow{2}{*}{\multicolumn{2}{|c|}{ Sum squared resid. }} & 3.259205 \\
\hline Durbin-Watson stat & 0.512910 & & & \\
\hline
\end{tabular}


Selanjutnya, peneliti memilih model fixed effect untuk memperkuat hasil analisis menggunakan common effect yang dilakukan sebelumnya. Hal ini karena datanya adalah data panel yaitu kombinasi antara time series dan cross section, sehingga model fixed effect lebih sesuai. Di samping itu, hasil yang diperoleh jauh lebih baik daripada menggunakan model regresi biasa (sederhana atau berganda). Untuk model random effect, model ini tidak dapat digunakan karena jumlah variabelnya harus lebih besar dari seri data yangada (2000-2010). Menurut Gujarati (2003), random effect di- asumsikan dapat menghasilkan estimator yang tidak efisien ketika distribusi datanya diprediksi tidak sesuai. Gujarati (2003) juga menyarankan bahwa random effect diasumsikan akan lebih baik ketika jumlah dari N (jumlah data) crosssection yang kecil. Alasan lain di balik pilihan model fixed effect adalah dari asumsi peneliti bahwa kondisi perusahaan tidak sama (Widarjono, 2007). Hasil model regresi panel dengan fixed effect ditunjukkan dalam Tabel 2. Penggunaan model fixed effect sebagai model dalam analisis statistik ini memperkuat keputusan di atas.

Table 2: Hasil Panel Regression dengan model Fixed Effect

\begin{tabular}{|c|c|c|c|c|}
\hline Variable & Coefficient & Std. Error & t-Statistic & Prob. \\
\hline GROWTH & 0.082673 & 0.026241 & -0.914382 & 0.2715 \\
\hline ASSET & 0.012618 & 0.007342 & 2.875398 & 0.0076 \\
\hline SIZE & 0.474523 & 0.030012 & 26.56442 & 0.0000 \\
\hline PROFIT & -0.367251 & $0.05 \$ 18$ & -4.783452 & 0.0000 \\
\hline \multicolumn{5}{|l|}{ Fixed Effects } \\
\hline BUMI - C & -1.125623 & & & \\
\hline BATA - C & -1.219827 & & & \\
\hline JPRS - C & -1.876382 & & & \\
\hline DAVO- C & -1.433266 & & & \\
\hline MRAT - C & -1.220196 & & & \\
\hline TLKM - C & -1.273894 & & & \\
\hline LTLS-C & -1.182973 & & & \\
\hline UNTR - C & -1.328376 & & & \\
\hline ULTJ - C & -1.612837 & & & \\
\hline MAID- C & -1.267311 & & & \\
\hline MPPA - C & -1.192873 & & & \\
\hline HEXA - C & -1.176283 & & & \\
\hline FAFO - C & -1.193425 & & & \\
\hline STTP - C & -1.317263 & & & \\
\hline CLPI - C & -1.372618 & & & \\
\hline LIMW - C & -1.126378 & & & \\
\hline ASII - C & -1.761127 & & & \\
\hline TURI - C & -1.287637 & & & \\
\hline BLTA - C & -1.228761 & & & \\
\hline HITS - C & -1.228918 & & & \\
\hline ISAT $-\mathrm{C}$ & -1.762940 & & & \\
\hline HERO - C & -1.673681 & & & \\
\hline PBRX - C & -1.217624 & & & \\
\hline \multicolumn{5}{|l|}{ Weighted Statistics } \\
\hline R-squared & $0.981 \$ 4$ & Mean & ident var & 1.421843 \\
\hline Adjusted R-squared & 0.98533 & S.D. $\mathrm{d}$ & lent var & 1.651432 \\
\hline S.E. of regression & 0.114678 & Sum s & d resid & $1.17 \$ 89$ \\
\hline F-statistic & 4123.158 & Durbir & son stat & 1.351977 \\
\hline Prob(F-statistic) & 0.000000 & & & \\
\hline
\end{tabular}


Menurut kedua hasil yang diperoleh dari 2 model (common dan fixed effect), model panel regresi yang terbaik dapat dilihat dari SE (standar error) regresinya. Model yang memiliki kesalahan regresi terkecil merupakan model yang terbaik dan akurat. Kesalahan regresi dari model fixed effect 0.114678, sementara model common effect adalah 0.171542 . Dengan demikian kita simpulkan bahwa model yang lebih baik adalah model fixed effect yang ditunjukkan pada Tabel 2 . Untuk menafsirkan hasil analisis yang ditampilkan pada Tabel 2, maka formulasi dengan model fixed effect dapat ditulis sebagai berikut:

$$
\begin{aligned}
\text { DEBT }= & -1.1256-1.2176+0.0827 \\
& \text { GROWTH }+0.0126 \text { ASSET }+0.4745 \\
& \text { SIZE }-0.3673 \text { PROFIT }+\mathrm{e} \\
\text { DEBT }= & -2.3432+0.0827 \text { GROWTH }+ \\
& 0.0126 \text { ASSET }+0.4745 \text { SIZE }- \\
& 0.3673 \text { PROFIT }+\mathrm{e}
\end{aligned}
$$

\section{Pengujian Hipotesis}

\section{Hubungan pertumbuhan (GROWTH) dengan rasio hutang (DEBT)}

Berdasarkan hasil analisis yang terlihat pada Tabel 2 di atas menunjukkan bahwa hasil uji-t untuk variabel pertumbuhan perusahaan (GROWTH) memiliki probabilitas 0,2175 yang berarti di atas nilai alfa 0,05 (5\%). Hal ini artinya bahwa Ho diterima atau Ho tidak ditolak, yang berarti hipotesis 1 (H1) yang menyatakan bahwa pertumbuhan perusahaan memiliki hubungan positif dengan leverage perusahaan adalah tidak signifikan atau ditolak. Hasil penelitian ini bertentangan dengan teori trade-off, yang menyatakan sebuah perusahaan dengan pertumbuhan yang cepat akan tergantung pada dana eksternal, dalam hal ini dana dari hutang. Selain itu, biaya emisi menjual saham biasa biasanya akan lebih tinggi daripada biaya untuk menerbitkan obligasi. Sebagai akibatnya, perusahaan dengan pertumbuhan yang cepat akan memiliki hutang lebih tinggi daripada perusahaan yang pertumbuhannya lambat.

\section{Hubungan struktur aset (ASSET) dengan rasio hutang (DEBT)}

Hasil uji t-test pada variabel struktur aset (ASSET) yang ditampilkan pada Tabel 2 menunjukkan hasil probabilitas sebesar 0,0076 yang berarti di bawah nilai alfa $0,05(5 \%)$. Hal ini menunjukkan bahwa koefisien regresi positif sebesar 0,0126 atas variabel ASSET memiliki dampak positif yang signifikan pada rasio leverage (DEBT). Oleh karena itu, hipotesis nol (Ho) ditolak dan hipotesis $\mathrm{H} 2$ diterima, yang berarti bahwa jika aset perusahaan memiliki hubungan positif dengan besarnya permintaan pinjaman (hutang). Perusahaan akan memiliki kecenderungan untuk meminjam lebih banyak jika aset perusahaan meningkat. Dengan demikian, sebuah perusahaan yang memiliki aset yang besar sebagai jaminan hutang cenderung menggunakan hutang yang lebih besar pula.

Berdasarkan teori trade-off, aset perusahaan akan mempengaruhi secara positif yang signifikan mempengaruhi besarnya leverage perusahaan. Harris dan Raviv (1990) mengasumsikan bahwa sebuah perusahaan dengan tingkat aktiva tetap yang rendah akan mendapatkan masalah lebih serius tentang informasi asimetris dibandingkan dengan perusahaan yang memiliki tingkat aktiva tetap lebih tinggi. Perusahaan yang memiliki tingkat aset tetap lebih tinggi adalah sebuah perusahaan besar. Hal ini juga menunjukkan bahwa perusahaan akan menjual saham mereka dengan tingkat harga yang adil dan mereka tidak menggunakan pinjaman untuk membiayai investasi mereka.

\section{Hubungan ukuran (SIZE) dengan rasio hutang (DEBT)}

Hasil uji-t hubungan antara ukuran perusahaan (SIZE) dengan rasio hutang (DEBT) menunjukkan bahwa nilai probabilitas pada Tabel 2 adalah 0,0000 yang kurang dari 0,05 (p $<0,05$ ), yang berarti Ho ditolak. Hasil ini juga menunjukkan bahwa koefisien regresi bernilai positif yaitu 0,4745 yang berarti ukuran perusahaan memiliki dampak positif dan signifikan terhadap rasio utang. Oleh karena itu hipotesis ketiga (H3) diterima, yang berarti bahwa ada korelasi atau hubungan positif antara ukuran perusahaan dan rasio utang dapat dibuktikan.

Jika kita melihat koefisien regresi yang positif, hal itu menunjukkan bahwa ukuran perusahaan lebih tinggi menyebabkan rasio hutang perusahaan yang lebih tinggi juga. 
Biasanya, hal ini karena perusahaan besar akan diikuti oleh sejumlah aset yang besar. Dengan aset mereka, sebuah perusahaan besar akan lebih mudah untuk mengajukan pinjaman dibanding perusahaan kecil. Sejumlah besar aset akan menjadi jaminan pemegang obligasi untuk mendapatkan pinjaman yang besar. Oleh karena itu, rasio hutang perusahaan bisa meningkat.

\section{Hubungan profitabilitas (PROFIT) dengan rasio hutang (DEBT)}

Hasil uji-t pada variabel profitabilitas (PROFIT) yang terlihat pada Tabel 2 menunjukkan nilai probabilitas sebesar 0,0000 yang kurang dari nilai $\alpha$ (alfa) sebesar 0,05 (p $<0,05)$. Dengan koefisien regresi negatif yaitu sebesar -0,3673, menunjukkan bahwa profitabilitas perusahaan akan mempengaruhi rasio hutang (DEBT) secara negatif dan signifikan. Hal ini berarti bahwa hubungan negatif antara profitabilitas dan rasio hutang terbukti ada. Dengan demikian, hipotesis nol (Ho) ditolak atau hipótesis keempat (H4) diterima. Keadaan ini konsisten dengan hasil kajian Mira (2001) yang meneliti mengenai penggunaan hutang pada perusahaan kecil. Beliau menemukan bahwa industri kecil cenderung menggunakan hutang yang lebih rendah ketika membiayai kegiatan bisnis mereka. Hal ini disebabkan oleh profitabilitas yang lebih besar dari perusahaan, semakin besar pula likuiditas perusahaan. Profitabilitas yang lebih besar akan menghasilkan saldo laba yang besar juga. Laba yang besar meningkatkan kemampuan perusahaan untuk menggunakan dana internal yang berasal dari laba tersebut yang berupa laba ditahan. Peningkatan sumber internal dari laba ditahan ini yang merupakan modal sendiri juga akan meningkat dan secara bersamaan akan menurunkan penggunaan hutang, sehingga rasio hutang terhadap aktiva juga menurun. Oleh karena itu, hubungan profitabilitas dengan rasio hutang adalah negatif. Artinya, semakin besar tingkat profitabilitas semakin kecil rasio hutang perusahaan. Kondisi ini sesuai dengan teori pecking order dan kajian Graham (2006) yang menemukan bahwa penggunaan dana internal akan mengurangi kebutuhan hutang perusahaan.

\section{PENUTUP}

Berdasarkan hasil pengujian hipotesis diperoleh kesimpulan bahwa pertumbuhan perusahaan (GROWTH) memiliki hubungan positif tetapi tidak signifikan dengan struktur modal atau rasio hutang (DEBT) sehingga hipotesis pertama tidak terbukti. Namun, struktur aset (ASSET) memiliki hubungan positif dan signifikan dengan struktur modal atau rasio hutang (DEBT), sehingga hipotesis kedua terbukti. Hipotesis ketika juga menunjukkan bahwa ukuran perusahaan (SIZE) memiliki hubungan positif dan signifikan dengan rasio hutang (DEBT), sehingga hipotesis ketiga terbuti. Dan profitabilitas (PROFIT) juga terbukti memiliki hubungan negatif dan signifikan dengan struktur modal atau rasio hutang (DEBT) sehingga hipotesis keempat terbukti. Secara serentak juga terbukti bahwa semua variabel independen yaitu pertumbuhan perusahaan, struktur aset, ukuran perusahaan dan kemampuan memperoleh keuntungan (profitability) berpengaruh secara signifikan terhadap struktur modal.

Berdasarkan hasil analisis yang diperoleh, beberapa rekomendasi untuk penelitian selanjutnya meliputi: Pertama, untuk variabel dalam hipotesis pertama ditemukan bahwa peluang pertumbuhan perusahaan tidak memiliki pengaruh yang signifikan pada rasio hutang. Oleh karena itu, untuk penelitian selanjutnya sebaiknya variabel rasionya diubah. Jika dalam penelitian ini komposisi rasio hutang adalah rasio antara hutang dengan perubahan dalam total aset, akan lebih baik jika hal ini diubah menjadi variabel lain seperti penjualan sehingga kita dapat menemukan hasil yang lebih baik dalam menganalisa hubungan peluang pertumbuhan dengan hutang. Kedua, penelitian selanjutnya akan lebih baik jika periode sampel penelitian ditambahkan lebih lama dan jumlah sampel lebih banyak sehingga informasi yang muncul lebih mendukung hasil yang diharapkan dan analisis panel regresi dengan model random effect dapat digunakan sehingga hasilnya kemungkinan akan lebih baik. Ketiga, jumlah rasio keuangan yang digunakan dalam penelitian harus diperluas sehingga hasilnya bisa lebih baik. 


\section{DAFTAR PUSTAKA}

Brigham, EF. and MC. Ehrhardt. 2005. Financial Management: Theory and Practice. Eleventh Edition, SouthWestern, Australia: Thomson Learning.

Frank, MZ. and VK. Goyal. 2005. Trade-off and Pecking Order Theories of Debt. Hong Kong University of Science \& Technology.

Graham, JR. 2006. Taxes and capital structure. http://www.entrepreneur.com/, retrieved on March 31, 2008.

Gujarati, D. 2003. Basic Econometrics. Fourth Edition New York: McGraw Hill.

Harris, M. and A. Raviv. 1990. Capital Structure and the Informational Role of Debt. The Journal of Finance, Vol. 45, No. 2. pp. 321-349.

Hovakimian, A., T. Opler and S. Titman, 2001. The debt-equity choice. $J$. of Financial and Quantitative Analysis, 36, 1.25.

Jensen, MC. and WH. Meckling. 1976. Theory of the firm: managerial behavior, agenc costs and ownership structure. Journal of Financial Economics 3: 305-360.
Mira, FS. 2001. On capital structure in the Small and Medium Enterprises: the Spanish case. Universidad Cardenal Herrera.

Modigliani, F. and MH. Miller. 1958. The cost of capital, corporation finance and the theory of investment. The American Review 47(3): 261-297.

Modigliani, F. and MH. Miller. 1963. Taxes And The Cost Of Capital: A Corretion. The American Economic Review: 433443.

Myers. S and Majluf. 1984. Corporate Financing and Investment Decision When Firms have information Investors Do not Have. Journal of Finance Economics 13: 187-221.

Taufik, N dan Harjito, DA. 2010. Capital Structure Analysis in the Application of Fiscal Theory, Trade Off Theory and Peccking Order Theory. Jurnal Ekonomi dan Bisnis EKOBIS, 7 (1): 55-65.

Widarjono, A. 2007. Ekonometrika: Teori dan Aplikasi. Ekonisia: Yogyakarta. 